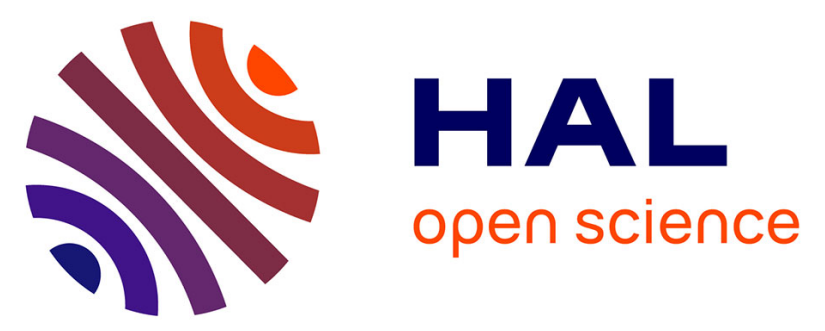

\title{
A preliminary study of habitat and resource partitioning among co-occurring tropical dolphins around Mayotte, south-west Indian Ocean
}

\author{
Alexandra Gross, Jeremy Kiszka, Olivier van Canneyt, Pierre Richard, \\ Vincent Ridoux
}

\section{To cite this version:}

Alexandra Gross, Jeremy Kiszka, Olivier van Canneyt, Pierre Richard, Vincent Ridoux. A preliminary study of habitat and resource partitioning among co-occurring tropical dolphins around Mayotte, south-west Indian Ocean. Estuarine, Coastal and Shelf Science, 2009, pp.367-374. hal-00606243

\section{HAL Id: hal-00606243 \\ https://hal.science/hal-00606243}

Submitted on 5 Jul 2011

HAL is a multi-disciplinary open access archive for the deposit and dissemination of scientific research documents, whether they are published or not. The documents may come from teaching and research institutions in France or abroad, or from public or private research centers.
L'archive ouverte pluridisciplinaire HAL, est destinée au dépôt et à la diffusion de documents scientifiques de niveau recherche, publiés ou non, émanant des établissements d'enseignement et de recherche français ou étrangers, des laboratoires publics ou privés. 
1 A preliminary study of habitat and resource partitioning among co-occurring tropical dolphins around Mayotte, south-west Indian Ocean

6 Gross Alexandra ${ }^{1}$, Kiszka Jeremy ${ }^{1,2}$, Van Canneyt Olivier $^{3}$, Richard Pierre ${ }^{1}$, Ridoux Vincent ${ }^{1,3^{*}}$ 7

13 1: LIttoral ENvironnement et Sociétés (LIENSs), UMR6250, Université de la Rochelle, 2 rue 14 Olympe de Gouges, 17000 La Rochelle, France.

15 2: Direction de l'Environnement et du Développement Durable, Collectivité Départementale de 16 Mayotte, BP 101, 97600 Mamoudzou, Mayotte, France. Email : jeremy.kiszka@wanadoo.fr

17 3: Centre de Recherche sur les Mammifères Marins, Université de la Rochelle, 23 avenue Albert 18 Einstein, F-17071 La Rochelle cedex, France.

19

$20 *$ Corresponding author: vincent.ridoux@univ-lr.fr

$21 \quad$ Tel.: +33(0)5.4644.9910 
Abstract

24 Mayotte in the southwest Indian Ocean is characterized by high dolphin diversity. They may coexist within a fairly small area around the island because they exploit neither the same preferential habitats nor the same resources. This preliminary study aimed to investigate ecological niche segregation among these delphinid communities: the Indo-Pacific bottlenose dolphin, Tursiops aduncus, the pantropical spotted dolphin, Stenella attenuata, the spinner dolphin, Stenella longirostris, and the melon-headed whale, Peponocephala electra. Two approaches were used. Habitat preferences were investigated by analysing dolphin sighting data

31 and associated physiographical characteristics. Resource partitioning was explored by analysing

$32 \mathrm{C}$ and $\mathrm{N}$ stable isotopes in skin and blubber biopsies. Only T. aduncus, which showed clear 33 association with coastal habitats in the lagoon, differed from the others in terms of habitat 34 preferences, characterised by shallow depth and slope, and proximity to the coast. All other species shared similar oceanic habitats immediately outside the lagoon, these being of higher depth and slope, greater distance from the coast and were not discernable by discriminant analysis. The two Stenella species and the melon-headed whale displayed very high overlap in habitat physiographic variables. The analysis of stable isotopes confirmed the ecological isolation of $T$. aduncus and revealed a clear segregation of P. electra compared to the two Stenella that was not apparent in the habitat analysis. This may reflect ecological differences that were not

41 observable from diurnal surface observations.

Key-words: dolphins, ecological niche, habitats, stable isotopes, south-west Indian Ocean, Mayotte. 


\section{Introduction}

In biological communities, each species has its own unique niche, which provides the conditions and resources needed for its survival. A shared resource in limited supply will bring about competition between members of the same species (intra-specific competition) or between individuals of different species (inter-specific competition). Competition can take two different forms: interference, which is a direct, often aggressive, interaction between individuals, or exploitation-competition, in which individuals interact with each other indirectly, by responding to a resource level which has been depressed by the activity of competitors (Begon et al., 1986). A niche occupied by a species in the absence of competitors is termed its fundamental niche, whereas in the presence of competitors, species may be confined to a realized niche, which is shaped by the presence of competing sympatric species (Begon et al., 1986). Hence, the coexistence of potentially competing species is often made possible by the differentiation of their realized ecological niches. The first mechanism that allows for niche differentiation is resource partitioning. In this case, different species living in the same habitat exploit the resources differently. For example, predators of different size may feed on prey of different size, hence minimising the overlap between the various predators' prey size ranges. Prey specialization presumably allows for niche partitioning in areas of sympatry (Ballance, 2002). The second mechanism involves spatial (microhabitat differentiation) or temporal separation in the availability of the different resources (these become available at different times of the day or different seasons of the year; Huisman and Weissing, 2001).

Small delphinids belong to numerous species which have similar morphological characteristics. This situation suggests that fine-scale mechanisms allow for the partitioning of habitats and resources when and where the different species live in sympatry. A study of the cetacean community of Great Abaco, Bahamas, has shown that the ecological niches of the four species 
that permanently live there do not overlap (MacLeod et al., 2004). These species capture prey at different depths of the water column. Other cetacean species are observed in the study area only during the season when prey abundance is sufficiently high to support their presence, while they are competitively excluded for the rest of the year (MacLeod et al., 2004). Indeed, the spatial distribution of marine predators is mainly determined by the distribution and availability of their prey, these in turn varying according to physical, chemical and biological characteristics of the water masses (Forcada, 2002).

The dietary ecology of marine mammals and their trophic level can be determined using different methods: traditional methods analyse faeces and regurgitated food of living animals, as well as the stomach contents of dead animals (from strandings or by-catch; e.g. Pusineri et al., 2007). A more recent method for studies of dietary ecology is stable isotope analysis of blubber, skin or muscle samples (Bearhop et al., 1993). The carbon and nitrogen isotope ratios $\left({ }^{13} \mathrm{C} /{ }^{12} \mathrm{C}\right.$ and ${ }^{15} \mathrm{~N} /{ }^{14} \mathrm{~N}$, expressed hereafter as $\delta^{13} \mathrm{C}$ and $\delta^{15} \mathrm{~N}$ ) of a consumer reflect those of its diet, with a slight retention of the heavier isotope and excretion of the lighter one (Das et al., 2003). As a consequence, tissues will be enriched with heavy isotopes at every trophic level. The minor stepwise trophic enrichment of the carbon-isotope ratio limits its use in assessing trophic levels, but enhances its use in tracking carbon sources through a food chain. The carbon isotope ratio of secondary and tertiary consumers should thus reflect the source of carbon at the base of their food chain (Kelly, 2000). The higher enrichment of the nitrogen isotope ratio of consumers compared to their prey makes it very useful for the determination of their trophic level (Kelly, 2000). Thus, both ratios help elucidate trophic relations and habitat use.

Mayotte, a volcanic island in the northern Mozambique Channel (southwest Indian Ocean), is characterized by the permanent presence of more than 20 species of cetaceans (Kiszka et al., 2007). Of these, the most important in coastal waters are the Indo-Pacific bottlenose dolphin, 
Tursiops aduncus (Ehremberg, 1833), the pan-tropical spotted dolphin, Stenella attenuata (Gray,

95 1846), the spinner dolphin, S. longirostris (Gray, 1828), and the melon-headed whale,

Peponocephala electra (Gray, 1846). The island has a great variety of marine ecosystems offering a large diversity of habitats: coasts, mangroves, an extended lagoon $\left(1100 \mathrm{~km}^{2}\right)$, different kinds of reefs (fringing, pinnacles, and barrier), a steep insular slope with many submarine canyons and seamounts, and the open ocean (Quod et al., 2000). At least twelve species of delphinids may coexist in a fairly small area around the island because they exploit neither the same habitats nor the same resources (Kiszka et al., 2007). The present study aimed to investigate ecological niche segregation among the resident dolphin community of Mayotte, especially the Indo-Pacific bottlenose dolphin, the pantropical spotted dolphin, the spinner dolphin and the melon-headed whale. We concentrated on these four species as they are of fairly similar size and can be found within the same proximity around Mayotte, in closely-related habitats within a small area and at all seasons (Kiszka et al., 2007). This is particularly so for the two Stenella species and the melon-headed whale which are all encountered immediately outside the barrier-reef and in the channels, whereas existing literature suggests that they would be more differentiated habitat-wise, with the spinner dolphin feeding offshore but resting inshore, the melon headed whale being an oceanic squid-eater and the Indo-Pacific bottlenose dolphin dwelling in nearshore coastal habitats (Norris et al., 1994; Silva et al., 2005; Perryman, 2002; Wells and Scott, 2002). Two approaches were used for the study: a comparison of habitat by the analysis of dolphin sighting data and associated behavioural and physiographic characteristics (group size, depth, slope, distance to the coast and proximity to the different kinds of reefs), and the study of habitat and resource partitioning by the analysis of $\mathrm{C}$ and $\mathrm{N}$ stable isotopes from skin and blubber biopsies. 


\section{Material and Methods}

1192.1 Study area

120 The volcanic island of Mayotte $\left(45^{\circ} 10^{\prime} \mathrm{E}, 12^{\circ} 50^{\prime} \mathrm{S}\right)$, which is part of the Comoros archipelago, is

121 located in the northern Mozambique Channel (Indian Ocean) between Madagascar and Southeast

122 Africa. Its surface area is $376 \mathrm{~km}^{2}$ and it is composed of two main islands and about 30 islets

123 scattered within and around a lagoon. Mayotte is surrounded by a large lagoon-reef complex,

124 whose width varies from 3 to $15 \mathrm{~km}$. Fringing reefs surround the archipelago, an inner double-

125 reef is present off the south-west end of Mayotte, and the barrier reef, which is interrupted by

126 numerous channels, separates the lagoon itself (maximum depth $80 \mathrm{~m}$ ) from the external slope

127 and more oceanic habitats.

128 The four species of interest, the Indo-Pacific bottlenose dolphin, the pantropical spotted dolphin,

129 the spinner dolphin, and the melon-headed whale, range in size from about $200 \mathrm{~cm}$ and $90 \mathrm{~kg}$ for

130 the spinner dolphin to $250 \mathrm{~cm}$ and $250 \mathrm{~kg}$ for the melon-headed whale (Perrin, 2002a and b,

131 Perryman, 2002, Wells and Scott, 2002).

132

133 2.2 Data and sample collection

134 Data were collected from 1997 to 2005, during small boat-based surveys dedicated to studying

135 marine mammals (Figure 1). Several types of boats were used: a $7 \mathrm{~m}$ catamaran equipped with

136 two, four-stroke, 60-hp outboard engines; a $7 \mathrm{~m}$ boat equipped with two, two-stroke, 40-hp

137 outboard engines; a 6.4 m cabin boat equipped with an inboard four-stroke and 150-hp outboard

138 engine. Surveys were conducted during daylight hours, i.e. between $0700 \mathrm{~h}$ and $1800 \mathrm{~h}$, in sea

139 conditions not exceeding Beaufort 3. The survey vessels did not follow pre-defined transects but

140 sampling covered all habitats within the lagoon and over the external insular slope (Figure 1).

141 Effort varied according to month (Figure 2), with more effort being applied in the austral summer 
142 (November to January). When dolphins were encountered, preliminary information records

143 included group size (maximum, minimum, best estimate), geographic position, activity

144 (travelling, resting, foraging/feeding, socialising, milling, play), group classification on the basis

145 of the relative size of individuals (adults, sub-adults, calves), research boat disturbance (bowride,

146 approach, avoidance, no response) as well as group formation (tight, loose, dispersed, variable,

147 convergent; Shane, 1990; Würsig et al., 1998). This study is still on-going and, therefore, only

148 the sighting locations and associated physiographic variables are analysed here.

149 When conditions were optimal (good weather and sea state, dolphins closely approaching the 150 boat), biopsies were collected using a cross-bow (BARNETT Veloci-Speed ${ }^{\circledR}$ Class) with Finn

151 Larsen bolts and tips (20-mm). The dolphins were hit below the dorsal fin, when close (3-10

152 meters) to the research boat. Sampling periods spanned all seasons but sample sizes did not allow

153 seasonal comparisons (January, August and December for T. aduncus, N=4; January, February,

154 March and October for S. attenuata, N=4; February, March, May and October for S. longirostris,

$155 \mathrm{~N}=5$; March, July and December for P. electra, N=4). It was not possible to determine sex, size

156 or age of the individuals biopsied. Blubber and skin biopsy samples were preserved separately in

$15790^{\circ}$ ethanol before shipping and subsequent analysis. Biopsy sampling was conducted under

158 scientific permit \#78/DAF/2004.

$160 \quad 2.3$ Database

161 We constituted a database in which every dolphin observation was associated with the 162 physiographic characteristics (distance to the coast, to the different reefs and to the closest 163 channel, as well as depth and slope of seafloor and the variance of these two parameters) 164 corresponding to the GPS (Global Positioning System) fixes of the observation. The distance data 165 were obtained using GIS (Geographic Information System) software ArcView (ArcGIS 8.2) by 
166 ESRI (Environmental Systems Research Institute). Bathymetric data were obtained from Service

167 Hydrographique et Océanographique de la Marine (SHOM). Interpolation of bathymetry data,

168 needed to generate depth and slope data for each sighting, was undertaken with the extension

169 Spatial Analyst by kriging transformation of the raster file into an interpolated data file. This was

170 obtained by calculating the mean value of the twelve points closest to every bathymetric point in

171 a $1 \mathrm{~km}^{2}$ grid. This interpolated data file thus allowed us to generate depth and slope data over the

172 whole study area and therefore to associate bathymetry data to any dolphin observation in the 173 area.

\subsection{Data analysis}

176 The environmental data were first compared between species using basic methods (non177 parametric analyses and ANOVA). Then we used multivariate statistical methods including 178 discriminant linear and quadratic analyses to examine how well sightings were assigned to the 179 correct species from the combination of associated physiographic variables. All methods were 180 implemented with the software R (R-2.2.1, R Development Core Team, 2005).

183 Blubber and skin were separated for each biopsy. The ethanol they contained was evaporated at $18445^{\circ} \mathrm{C}$ over $48 \mathrm{~h}$ and the samples were ground and freeze-dried (Hobson et al., 1997). Lipids were 185 extracted using cyclohexane $\left(\mathrm{C}_{6} \mathrm{H}_{12}\right)$ prior to analysis because they are depleted in ${ }^{13} \mathrm{C}$; if they 186 were not extracted, this would cause a bias in the isotopic signature of ${ }^{13} \mathrm{C}$ (De Niro and Epstein, 187 1978; Tieszen et al., 1983). Small sub-samples (0.35 to $0.45 \mathrm{mg} \pm 0.001 \mathrm{mg})$ were prepared for 188 analysis. Stable isotope measurements were performed with a continuous-flow isotope-ratio mass 189 spectrometer (Isoprime, Micromass) coupled to an elemental analyser (Eurovector EA 3024). 
191 Results are expressed in $\delta$ notation relative to PeeDee Belemnite and atmospheric $\mathrm{N}_{2}$ for $\delta^{13} \mathrm{C}$ and

$192 \delta^{15} \mathrm{~N}$, respectively, according to the equation $\delta \mathrm{X}=\left[\left(\mathrm{R}_{\text {sample }} / \mathrm{R}_{\text {standard }}\right)-1\right] \times 10^{3}$, where $\mathrm{X}$ is ${ }^{13} \mathrm{C}$ or

$193{ }^{15} \mathrm{~N}$ and $\mathrm{R}$ is the isotope ratio ${ }^{13} \mathrm{C} /{ }^{12} \mathrm{C}$ or ${ }^{15} \mathrm{~N} /{ }^{14} \mathrm{~N}$, respectively. Replicate measurements of internal

194 laboratory standards (acetanilide) indicated that measurement errors were $<0.15 \%$ and $<0.20 \%$ o

195 for $\delta^{13} \mathrm{C}$ and $\delta^{15} \mathrm{~N}$, respectively. Percent $\mathrm{C}$ and $\mathrm{N}$ elemental composition of tissues were obtained 196 using the elemental analyzer and used to calculate the sample C:N ratio, indicating a good lipid 197 removal efficiency when $<4$.

198

\section{3. Results}

\section{$200 \quad 3.1$ General}

201 Our cetacean sightings comprised 394 positional data for $S$. longirostris $(n=208)$, S. attenuata $(n$ $202=88), T$. aduncus $(n=83)$ and P. electra $(n=15)$ in all sectors around Mayotte (Figure 2$)$ and all 203 seasons (Figure 3). Indo-Pacific bottlenose were mostly found within the lagoon, very often in 204 the immediate proximity of the fringing reef, and to a lesser extent over the North West bank 205 located outside the main barrier reef. The two Stenella species were observed all along the barrier 206 reef on its outer side and made only a few incursions into the lagoon. Finally, the melon-headed 207 whale was only seen outside the barrier reef.

$209 \quad 3.2$ Habitat use and niche partitioning

210 A preliminary Principal Component Analysis (PCA plot not shown) allowed us to select group 211 size, distance to coast, depth and slope as the set of physiographic variables with least 212 redundancy. Distances to the various reefs and to the nearest channel were heavily redundant 
213 relative to distance from coast and therefore not retained. A simple comparison of the distribution

214 of these variables for the four focal species was performed using Kruskall-Wallis tests (Figure 4).

215 T. aduncus is observed at short distances from the coast with shallow bathymetry and moderate

216 slopes, whereas the other three species cannot be significantly differentiated in terms of habitat

217 characteristics. In particular, the two Stenella species manifested similar characteristics in group

218 size and environmental preferences. On the other hand, group size differed strongly between $T$.

219 aduncus that lives in small groups (median $=6$ ) and $P$. electra that is mostly found in groups of

220 several hundred individuals $($ median $=300)$.

221 Linear discriminant analysis separated the species according to their environmental 222 characteristics (Figure 5). The predictive power of the linear discriminant analysis was good only 223 for T. aduncus which can be explained by its habitat preferences (Table 1, upper part). The other 224 species' habitat characteristics were too similar to permit acceptable predictions. The good 225 prediction for $S$. longirostris might be attributable only to the considerable number of sighting 226 data for this species. Finally, the quadratic discriminant analysis provided slightly better 227 predictive results, especially for P. electra (Table 1, lower part).

228 The different methods used to compare the preferred habitats of the four delphinid species under 229 study all clearly showed that $T$. aduncus differs from the other species in its preferred 230 environmental parameters. S. attenuata and S. longirostris share similar environmental 231 characteristics. $P$. electra is characterised by a larger group size and deeper depth preference, but 232 resembles Stenella in terms of the majority of its other environmental preferences (distance and 233 slope).

$235 \quad 3.3$ Resource partitioning 
236 Stable isotope ratios were lower in blubber than in skin but the pattern of differences observed 237 between species was similar in both tissues (Figure 6). Skin and blubber of T. aduncus have the 238 highest values of $\delta^{13} \mathrm{C}$. The two Stenella species are not discernable from each other as shown by 239 the extensive overlap in standard deviation for both $\delta^{15} \mathrm{~N}$ and $\delta^{13} \mathrm{C}$, and have the lowest values for $240 \quad \delta^{13}$ C. P. electra has the highest $\delta^{15} \mathrm{~N}$ and a $\delta^{13} \mathrm{C}$ values that are intermediate between those for the

241 two Stenella species and T. aduncus. The intra-specific variance is represented by the standard 242 deviation, which is more important for the $\delta^{13} \mathrm{C}$ values than for the $\delta^{15} \mathrm{~N}$, except in the blubber 243 samples of T. aduncus where intra-specific variance in the $\delta^{15} \mathrm{~N}$ is prevalent.

\section{Discussion}

247 The present study comprises a preliminary analysis of habitat and resource use among an 248 assemblage of co-existing tropical delphinids living around Mayotte in the southwest Indian 249 Ocean. The principal finding is that, among the four species of interest, the Indo-Pacific 250 bottlenose dolphin is clearly differentiated from the other species in terms of both habitat 251 preference and stable isotope analyses. From the variables tested here, the other three species can 252 hardly be separated in terms of their preferred habitats but stable isotope analysis revealed a 253 dietary segregation between the melon-headed whale and the two species of the genus Stenella. 254 This was not initially evident in the sighting data analyses that described the dolphins' diurnal 255 use of habitats. However, some limitations render these findings preliminary. The sightings 256 constituted presence-only data as the observation effort could not be readily quantified and, 257 hence, the data cannot provide significant information concerning dolphin absence. In this work, 258 we tried to characterise the habitats where dolphins were found, not assess the overall distribution 259 of each species around the island. Nevertheless, the field surveys comprehensively covered the 
study area such that all habitats were visited and the sighting data of the four focal species were

261 considered representative of their habitat preference.

263 The Indo-Pacific bottlenose dolphin, Tursiops aduncus, occupies an ecological niche that clearly

264 differs from those occupied by the other study species. T. aduncus was observed only inside the 265 lagoon except in the northern part of the island where the reef system is in the form of an open 266 bank outside the lagoon. This species is generally found close to the fringing reef which 267 constitutes the ecosystem where prey of this coastal dolphin may be concentrated. The high $\delta^{13} \mathrm{C}$ 268 value in its tissues indicates a benthic carbon source that dolphins more easily access in coastal 269 habitats (Hobson, 1999). This species has indeed been observed feeding near mangroves, along 270 the fringing reefs or over seagrass beds. Its isotopic signature of $\delta^{15} \mathrm{~N}$ is similar to that of the two 271 Stenella, but this cannot be interpreted as an indication of similar trophic levels as the $\delta^{15} \mathrm{~N}$ values 272 of the local primary producers versus those outside the lagoon have not been investigated at this 273 stage.

274 T. aduncus lives and forages individually or in small groups inside the lagoon, where the water is 275 shallow and large predators are absent, and probably feeds on prey that would not aggregate in 276 large schools (Mann et al., 2000). Indo-Pacific bottlenose dolphins forage over reefs or soft 277 bottom substrata and near the shore relatively close to the island of Mayotte and around Zanzibar 278 (Tanzania) (Amir et al., 2005).

279 The pantropical spotted dolphin and the spinner dolphin share a barrier reef-associated habitat 280 outside the lagoon. They are also found where the water depth rapidly attains a depth of $100 \mathrm{~m}$. 281 In comparison to the Indo-Pacific bottlenose dolphin, their tissues had a lower $\delta^{13} \mathrm{C}$, suggesting it 282 was derived from an oceanic carbon source; oceanic phytoplankton is reported to be ${ }^{13} \mathrm{C}$-depleted 
283 relative to marine phanerogams (Hobson, 1999). Their isotopic ratios suggested their diet 284 comprised oceanic prey.

285 S. attenuata and S. longirostris can occasionally be observed inside the lagoon where they might 286 take advantage of the safety it provides for resting. This kind of behaviour has been observed in 287 Hawaiian spinner dolphin populations (Norris et al., 1994). S. longirostris generally lives in 288 single-species groups from several dozens to several hundreds of individuals, e.g. around the 289 main Hawai'i island (Norris et al., 1994). Their aggregation in large groups might offer some 290 protection against predators but it might also facilitate feeding through communal hunting on 291 large pelagic fish schools. In the present work, S. attenuata was rarely observed in single-species 292 groups but was generally found in association with S. longirostris, forming important mixed293 species groups. Both species might take advantage of a larger group size for safety and foraging. 294 Nevertheless, a large group size increases the potential for intra-specific competition as well as 295 inter-specific competition if the two species feed together. A study in the southwest Atlantic has 296 shown that distributions of spotted dolphins and spinner dolphins may partially overlap (Moreno 297 et al., 2005). Associations of spotted dolphins and spinner dolphins are frequently found in 298 Hawai' $i$, where the two species travel together while showing many aggressive interactions, but 299 they do not seem to feed together (Psarakos et al., 2003). Conversely, in the Azores, common 300 dolphins, Delphinus delphis, and Atlantic spotted dolphins, Stenella frontalis, associate and 301 forage together (Clua and Grosvalet, 2001). As S. attenuata and S. longirostris have similar 302 habitat preferences and similar isotopic signatures, both for carbon and nitrogen, there is no 303 evidence of ecological niche differentiation in these two species. Two options could be 304 investigated in the future: either the two dolphins share the same resources in the same habitats, 305 presumably because food is not limiting there, or they segregate when feeding on different 
resources but their prey have similar isotopic signatures because they rely on the same carbon

307 source at the same trophic level.

308 The melon-headed whale, Peponocephala electra, prefers steep slopes and slightly deeper water

309 than the two Stenella species. Peponocephala electra forms large groups of several hundred

310 individuals. As it was always observed in a habitat that overlaps with that of the spinner and

311 spotted dolphins, analysis of its habitat characteristics failed to distinguish between it and the two

312 Stenella species. This might be due to the fact that melon-headed whale sightings were only made

313 on groups that occasionally approached the island, as the surveys were conducted in a limited

314 area around Mayotte and groups living farther offshore in the open ocean would not have been

315 observed. In this case, our understanding of the preferred habitat of this species remains marginal,

316 being limited to its nearshore fringe. Stable isotope analysis, on the other hand, clearly showed

317 that there is an ecological differentiation between P. electra and the two Stenella species. Values

318 of $\delta^{13} \mathrm{C}$ for P. electra's were intermediate between those of the Stenella species and T. aduncus.

319 This would suggest that carbon isotopic composition of $P$. electra is influenced more by benthic

320 primary production than that of the two Stenella species. Peponocephala electra is known for its

321 oceanic habitat (Perryman, 2002), and possible interpretations for its $\delta^{13} \mathrm{C}$ include the possibility

322 that it is a deep-diving species that feeds on prey derived from a detritus-based food web unlike

323 the Stenella that feed on a phytoplankton-based food web. In addition, P. electra clearly differs in

324 its $\delta^{15} \mathrm{~N}$, this being indicative of a higher trophic level, suggesting its diet includes more

325 carnivorous fish and squid than the spotted and spinner dolphins. Again, as in T. aduncus, all

326 sources of primary production should be investigated concerning their $\delta^{15} \mathrm{~N}$ to adequately

327 interpret the trophic levels. 
329 If there is high inter-individual variance in the $\delta^{15} \mathrm{~N}$ (versus $\delta^{13} \mathrm{C}$ ) values within a species, the

330 interpretation is that the species is composed of individuals that have varied feeding habits and 331 prey on organisms at different trophic levels $\left(\delta^{15} \mathrm{~N}\right)$ or are found in different habitats $\left(\delta^{13} \mathrm{C}\right)$. A

332 low variance indicates that all the individuals are specialist feeders on similar prey or within the 333 same habitat. Thus, stable isotope variance is sometimes considered a measure of niche width 334 (Bearhop et al., 2004) or at least the inter-individual measure of niche width. Results of our stable 335 isotope analysis indicate that $P$. electra is a fairly specialized feeder, whereas $S$. attenuata, $S$. 336 longirostris and especially T. aduncus would be more eclectic feeders, which, in the latter case, is 337 in line with previous studies (Mann et al., 2000).

339 Detectable differences between the standard deviations in the stable isotope composition in the 340 skin and blubber samples might be attributable to their differential rates in tissue renewal: this 341 takes a few days for epidermis but several months for the collagen matrix of the blubber (Abend 342 and Smith, 1995). The residence time of elements in tissues depends on metabolic turnover rates 343 (Rubenstein and Hobson, 2004). This enables tracking of an animal's foraging history as 344 demonstrated by a study on pilot whales (Globicephala melas) in the North Atlantic (Abend and 345 Smith, 1995). T. aduncus and the two Stenella species clearly differ in the respective isotopic 346 carbon signatures in their skin and blubber, indicating that they feed on trophic webs with 347 different carbon sources over the long term.

348 Each species' habitat preference is presumably based on their prey distributions (Baumgartner et 349 al., 2000) which, in turn, are related to water depth (Hastie et al., 2005) and, indirectly, 350 bathymetric features that influence currents and productivity (Fiedler, 2002). Foraging behaviour 351 seems to be closely related to submarine habitat characteristics (Hastie et al., 2004). It has been 352 demonstrated that a variable bathymetry contributes to global delphinid abundance, promoting 
353 the regional abundance of different species (Gannier, 2005). The rich marine biodiversity of

354 Mayotte is possibly related to its variety of habitats and these provide numerous ecological niches 355 for delphinid prey.

\section{Conclusions}

358 The present study provides preliminary ecological indications of niche differentiation and 359 resource partitioning within the Mayotte delphinid communities. The only species that differs 360 from the others in terms of habitat characteristics is the coastal-dwelling Indo-Pacific bottlenose 361 dolphin, whereas pantropical spotted and spinner dolphins and the melon-headed whale share 362 similar oceanic habitats immediately outside the lagoon. Stable isotope analysis confirmed the 363 ecological specialisation of $T$. aduncus and, in addition to this, revealed a clear segregation of $P$. 364 electra, from to the two Stenella species in terms of their feeding that was not apparent in the 365 habitat analysis. This may reflect behavioural differences that were not detectable from diurnal 366 surface observations. Further work should strengthen these conclusions through dedicated 367 sampling of habitat preference and an expansion of the stable isotope studies. These should focus 368 on seasonal changes in food partitioning and the isotopic composition of a series of putative prey 369 species and primary producers characteristic of the inshore-offshore gradient of habitats found 370 around Mayotte.

\section{Acknowledgements}

373 Sightings were collected from 1997 to 2004 during the austral winter (July to October) as part of 374 the humpback whale (Megaptera novaeangliae) surveys conducted by the Observatoire des 375 Mammifères Marins de Mayotte (Direction de l'Agriculture et de la Forêt, DAF) and the 376 Cetacean Conservation and Research Program (American Museum of Natural History-Wildlife 
377 Conservation Society). The other sightings were collected from November 2004 to August 2005

378 during a dolphin research project conducted by the Office National de la Chasse et de la Faune 379 Sauvage (ONCFS) and the Agriculture and Forestry Office (Direction de l'Agriculture et de la 380 Forêt). We thank Peter Ersts (American Museum of Natural History, Center for Biodiversity and 381 Conservation) for providing the map showing tracks of the cetacean surveys conducted around 382 Mayotte. We are particularly grateful to Gaël Guillou (Université de la Rochelle) for undertaking 383 the mass spectrometer analyses. Funding for field work was provided by the Ministère de 384 l'Energie, l'Ecologie, le Développement Durable et de l'Aménagement du Territoire 385 (MEEDDAT) and the Collectivité Départementale de Mayotte (CDM). We thank Robin Rolland, 386 Alban Jamon, Wilfrid Fousse, Ismaël Ousseni (DAF), Sarah Caceres, Franck Charlier, Denis 387 Girou (ONCFS), Didier Fray (CDM) and the personnel of Brigade Nature (CDM) for assistance 388 in the field in Mayotte.

\section{References}

392 Abend, A.G., Smith, T.D., 1995. Differences in ratios of stable isotopes of nitrogen in long393 finned pilot whales (Globicephala melas) in the western and eastern North Atlantic. ICES Journal 394 of Marine Science 52: 837-841.

396 Amir, O.A., Berggren, P., Ndaro, S.G.M., Jiddawi, N.S., 2005. Feeding ecology of the Indo397 Pacific bottlenose dolphin (Tursiops aduncus) incidentally caught in the gillnet fisheries off 398 Zanzibar, Tanzania. Estuarine Coastal and Shelf Science 63: 429-437. 
400 Ballance, L.T. 2002. Cetacean Ecology. In: Perrin, W.F., Würsig, B., Thewissen, J.G.M.

401 (Editors), Encyclopedia of Marine Mammals, Academic Press, San Diego, pp 208-214.

402

403 Baumgartner, M.F., Mullin, K.D., May, L.N., Leming, T.D., 2001. Cetacean habitats in the 404 northern Gulf of Mexico. Fishery Bulletin 99: 219-239.

405

406 Bearhop, S., Adams, C.E., Waldron, S., Fuller, R.A., Macleod, H., 2004. Determining trophic 407 niche width: A novel approach using stable isotope analysis. Journal of Animal Ecology 73: 408 1007-1012.

409

410 Begon, M., Harper, J.L., Townsend, C.R., 1986. Ecology - Individuals, Populations and 411 Communities. Blackwell Scientific Publications, Boston, 876 pp.

413 Chapman, J.L., Reiss, M.J., 1999. Ecology - Principles and Applications. Cambridge University 414 Press, Cambridge, 336 pp.

415

416 Clua, E., Grosvalet, F., 2001. Mixed-species feeding aggregation of dolphins, large tunas and 417 seabirds in the Azores. Aquatic Living Resources 14: 11-18.

419 Das, K., Lepoint, G., Leroy, Y., Bouquegneau, J.M., 2003. Marine mammals from the southern 420 North Sea: feeding ecology data from $\delta 13 \mathrm{C}$ and $\delta 15 \mathrm{~N}$ measurements. Marine Ecology Progress 421 Series 263: 287-298. 
423 De Niro, M.J., Epstein, S., 1978. Influence of diet on the distribution of carbon isotopes in 424 animals. Geochimica Cosmochimica Acta 42: 495-506.

426 Estep, M.F., Dabrowski, H., 1980. Tracing food webs with stable hydrogen isotopes. Science $427 \quad 209: 1537-1538$.

429 Fiedler, P.C., 2002. Ocean environment. In: Perrin, W.F., Würsig, B., Thewissen, J.G.M. 430 (Editors), Encyclopedia of Marine Mammals, Academic Press, San Diego, pp 824-830.

432 Forcada, J., 2002. Distribution. In: Perrin, W.F., Würsig, B., Thewissen, J.G.M. (Editors), 433 Encyclopedia of Marine Mammals, Academic Press, San Diego, pp 325-333.

435 Gannier, A., 2005. Summer distribution and relative abundance of delphinids in the 436 Mediterranean Sea. Revue d'Ecologie (Terre et Vie) 60: 223-238.

438 Hastie, G.D., Swift, R.J., Slesser, G., Thompson, P.M., Turrell, W.R., 2005. Environmental 439 models for predicting oceanic dolphin habitat in the Northeast Atlantic. ICES Journal of Marine $440 \quad$ Science 62: 760-770.

442 Hastie, G.D, Wilson, B., Wilson, L.J., Parsons, K.M., Thompson, P.M. 2004. Functional 443 mechanisms underlying cetacean distribution patterns: hotspots for bottlenose dolphins are linked 444 to foraging. Marine Biology 144: 397-403. 
446 Hobson, K.A., 1999. Tracing origins and migration of wildlife using stable isotopes: a review.

447 Oecologia 120: 314-326.

448

449 Hobson, K.A., Gibbs, H.L., Gloutney, M.L. 1997. Preservation of blood and tissue samples for

450 stable-carbon and stable-nitrogen isotope analysis. Canadian Journal of Zoology 75:1720-1723.

Huisman, J., Weissing, F.J., 2001. Biological conditions for oscillations generated by multispecies oscillations. Ecology 82: 2682-2695.

Kelly, J.F., 2000. Stable isotopes of carbon and nitrogen in the study of avian and mammalian trophic ecology. Canadian Journal of Zoology 78: 1-27.

Kiszka, J., Ersts, P.J., Ridoux, V., 2007. Cetacean diversity around the Mozambique Channel

459 island of Mayotte (Comoros Archipelago). Journal of Cetacean Research and Management 9: $460 \quad 105-109$.

462 Macleod, C.D., Hauser, N., Peckham, H., 2004. Diversity, relative density and structure of the 463 cetacean community in summer months east of Great Abaco, Bahamas. Journal of the Marine 464 Biological Association of the U.K. 84: 469-474.

466 Mann, J., Connor, R.C., Tyack, P.L., Whitehead, H., 2000. Cetacean Societies - Field Studies of 467 Dolphins and Whales. University of Chicago Press, Chicago, 433 pp. 
469 Moreno, I.B., Zerbini, A.N., Danilewicz, D., De Oliveira Santos, M.C., Simoes-Lopes, P.C.,

470 Lailson-Brito, Jr. J., Azevedo, A.F., 2005. Distribution and habitat characteristics of dolphins of 471 the genus Stenella (Cetacea: Delphinidae) in the southwest Atlantic Ocean. Marine Ecology 472 Progress Series 300: 229-240.

474 Norris, K.S., Würsig, B., Wells, R. S., Würsig, M., 1994. The Hawaiian Spinner Dolphin, 475 University of California Press, Berkeley, 408 pp.

477 Perrin, W.F., 2002a. Pantropical spotted dolphin Stenella attenuata. In: Perrin, W.F., Würsig, B., 478 Thewissen, J.G.M. (Editors), Encyclopedia of Marine Mammals, Academic Press, San Diego, pp $479 \quad 865-867$.

480

481 Perrin, W.F., 2002b. Spinner dolphin Stenella longirostris. In: Perrin, W.F., Würsig, B., 482 Thewissen, J.G.M. (Editors), Encyclopedia of Marine Mammals, Academic Press, San Diego, pp $483 \quad 1174-1178$.

485 Perrin, W.F., Würsig, B., Thewissen, J.G.M., 2002. Encyclopedia of Marine Mammals, 486 Academic Press, San Diego, 1414 pp.

487

488 Perryman, W.L., 2002. Melon-headed whale Peponocephala electra. In: Perrin, W.F., Würsig, 489 B., Thewissen, J.G.M. (Editors), Encyclopedia of Marine Mammals, Academic Press, San Diego, $490 \quad$ pp 733-735. 
Psarakos, S., Herzing, D.L., Marten, K., 2003. Mixed-species associations between Pantropical 493 spotted dolphins (Stenella attenuata) and Hawaiian spinner dolphins (Stenella longirostris) off 494 Oahu, Hawaii. Aquatic Mammals 29: 390-395.

Quod, J.P., Naim, O., Abdourazi, F., 2000. The Comoros archipelago. In: Sheppard, C. (Editors), Seas at the Millennium: An Environmental Evaluation. Pergamon Press, Oxford, pp 243-52.

R Development Core Team, 2005. R: A language and environment for statistical computing. R Foundation for Statistical Computing. Vienna, Austria. (http://www.Rproject.org)

Pusineri, C., Magnin, V., Meynier, L., Spitz, J., Hassani, S., Ridoux, V., 2007. Food and feeding ecology of the common dolphin (Delphinus delphis) in the northeast Atlantic and comparison with its diet in neritic areas. Marine Mammal Science 23: 30-47.

506 Rubinstein, D.R., Hobson, K.A., 2004. From birds to butterflies: animal movement patterns and 507 stable isotopes. Trends in Ecology and Evolution 19: 256-263.

509 Silva, J.M., Silva, F.J.L., Sazima, I., 2005. Rest, nurture, sex, release, and play: diurnal 510 underwater behaviour of the spinner dolphin at Fernando de Noronha Archipelago, SW Atlantic. 511 Journal of Ichthyology and Aquatic Biology 9: 161-176.

513 Tieszen, L.L., Boutton, T.W., Tesdahl, K.G., Slade, N.A., 1983. Fractionation and turnover of 514 stable carbon isotopes in animal tissues: implications for $\delta^{13} \mathrm{C}$ analysis of diet. Oecologia 57: 32 $515 \quad 37$. 
517 Shane, S.H., 1990. Behaviour and ecology of the bottlenose dolphin at Sanibel Island, Florida. In:

518 S. Leatherwood, R.R. Reeves (Editors.). The Bottlenose Dolphin. Academic Press, San Diego, 519 pp. 256-266.

520

521 Wells, R.S., Scott, M.D., 2002. Bottlenose dolphins Tursiops truncatus and T. aduncus. In:

522 Perrin, W.F., Würsig, B., Thewissen, J.G.M. (Editors), Encyclopedia of Marine Mammals, 523 Academic Press, San Diego, pp 122-128.

525 Würsig, B., Lynn, S.K., Jefferson, T.A., Mullin, K.D., 1998. Behaviour of cetaceans in the 526 Northern Gulf of Mexico relative to survey ships and aircraft. Aquatic Mammals 24: 41-50. 


\section{Figure captions}

531 Figure 1: Location of the study area and observation routes from July 2004 to August 2005.

532 Isobath (left) and GPS tracks of sighting surveys (right) are shown around Mayotte Island with 533 barrier reef.

534 Figure 2: General locations of delphinid sightings around Mayotte and its reefs.

535 Figure 3: Temporal distribution of effort expressed as number of sightings per three-month 536 period.

537 Figure 4: Delphinid sighting median values, 50, 75 percentiles and outliers of (a) group size, (b) 538 distance to the coast, (c) depth and (d) seafloor slope. Kruskal Wallis tests showed that $T$. 539 aduncus differed significantly in all cases with $p$-values $<10^{-6}$.

540 Figure 5: Sighting density for melon-headed whale (dotted line), pan-tropical spotted (black 541 line), spinner (dashed line) and Indo-Pacific bottlenose dolphin (dashed and dotted line) along the 542 first discriminant axis.

543 Figure 6: Stable isotope $\left(\delta^{13} \mathrm{C}\right.$ and $\delta^{15} \mathrm{~N}$ in \%o) values in delphinid blubber (right-hand graph) 544 and skin (left-hand graph). Graphs show average values and standard deviations. Black squares 545 represent $S$. longirostris $(\mathrm{N}=5)$, whites squares $S$. attenuata $(\mathrm{N}=4)$, black diamonds $T$. aduncus $546(\mathrm{~N}=4)$ and white diamonds $P$. electra $(\mathrm{N}=4)$. 
547 Table 1: Discriminant analysis: linear and quadratic predictions for the four species. Each

548 sighting was assigned to one of the four study species on the basis of its associated physiographic

549 characteristics. Only T. aduncus data were correctly assigned to the right species whereas all

550 others were mostly assigned to $S$. longirostris as they all share similar habitat characteristics.

\section{$551 \quad$ Linear discriminant analysis}

\section{3}

557

558

S. longirostris $\quad 12$

T. aduncus $\quad 0$

559

560

Good prediction $14 \%$

\section{Quadratic discriminant analysis}

563

4

\section{8}

46

19
18

131

55

78 
$575 \quad$ Fig. 1

576

577

578

579

580

581

582

583

584

585

586
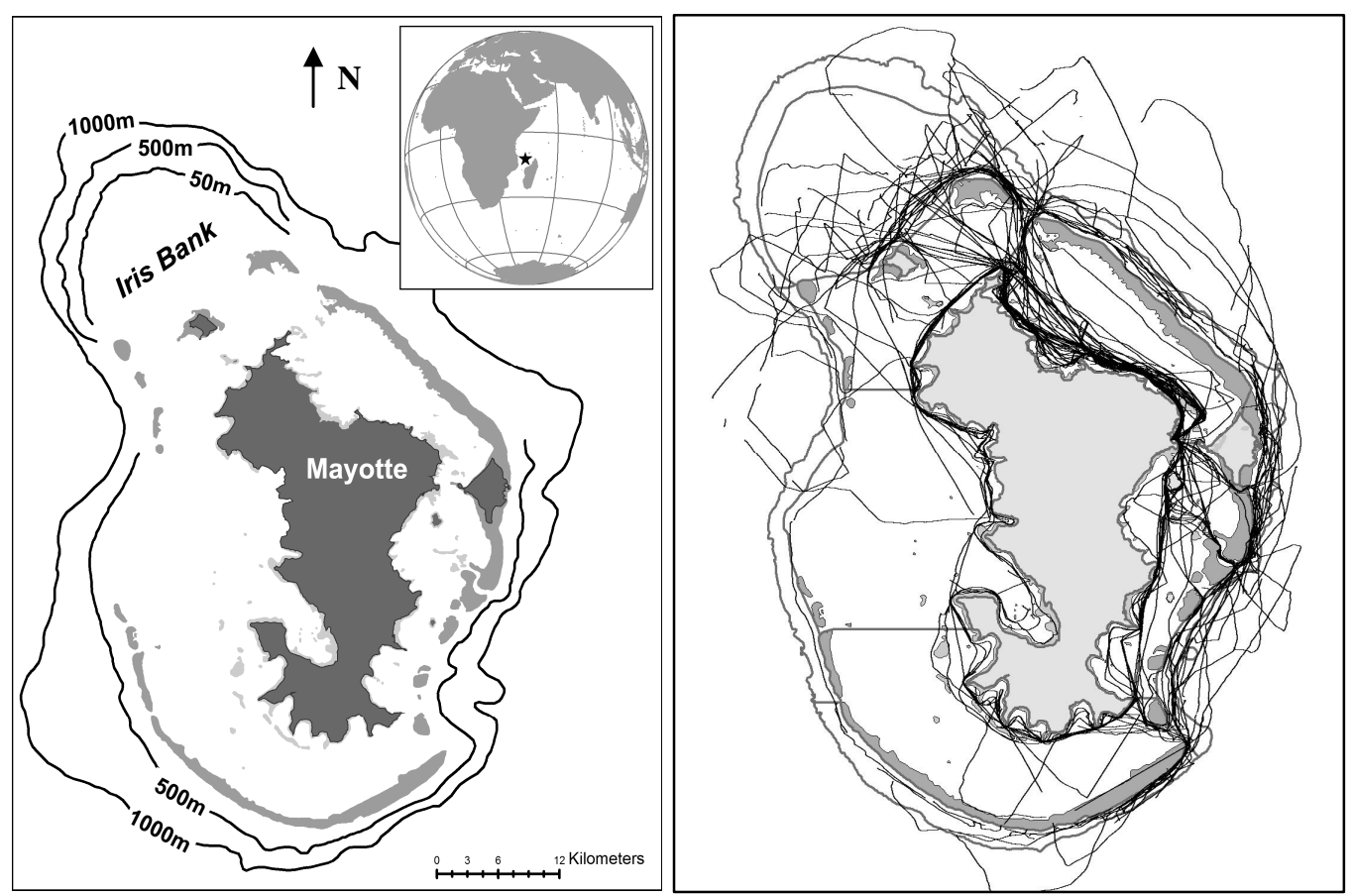

587

588

589

590

591

592

593

594

595

596 
597

$598 \quad$ Fig.2

599

600

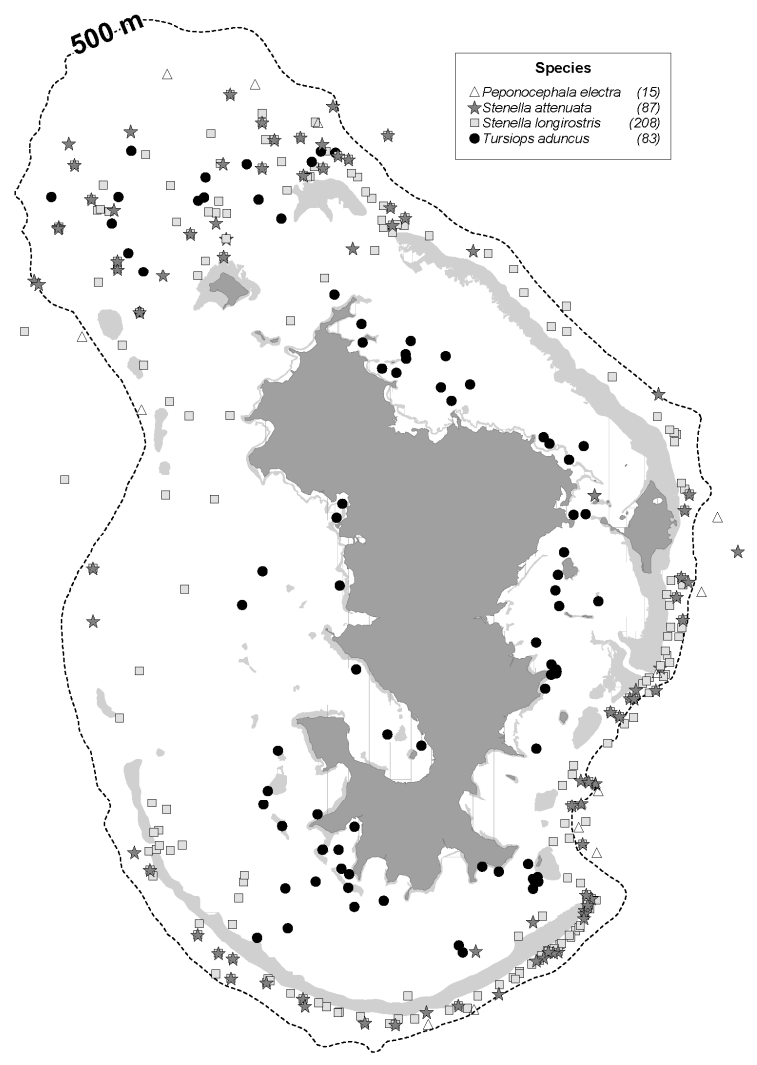


$601 \quad$ Fig.3

602

603

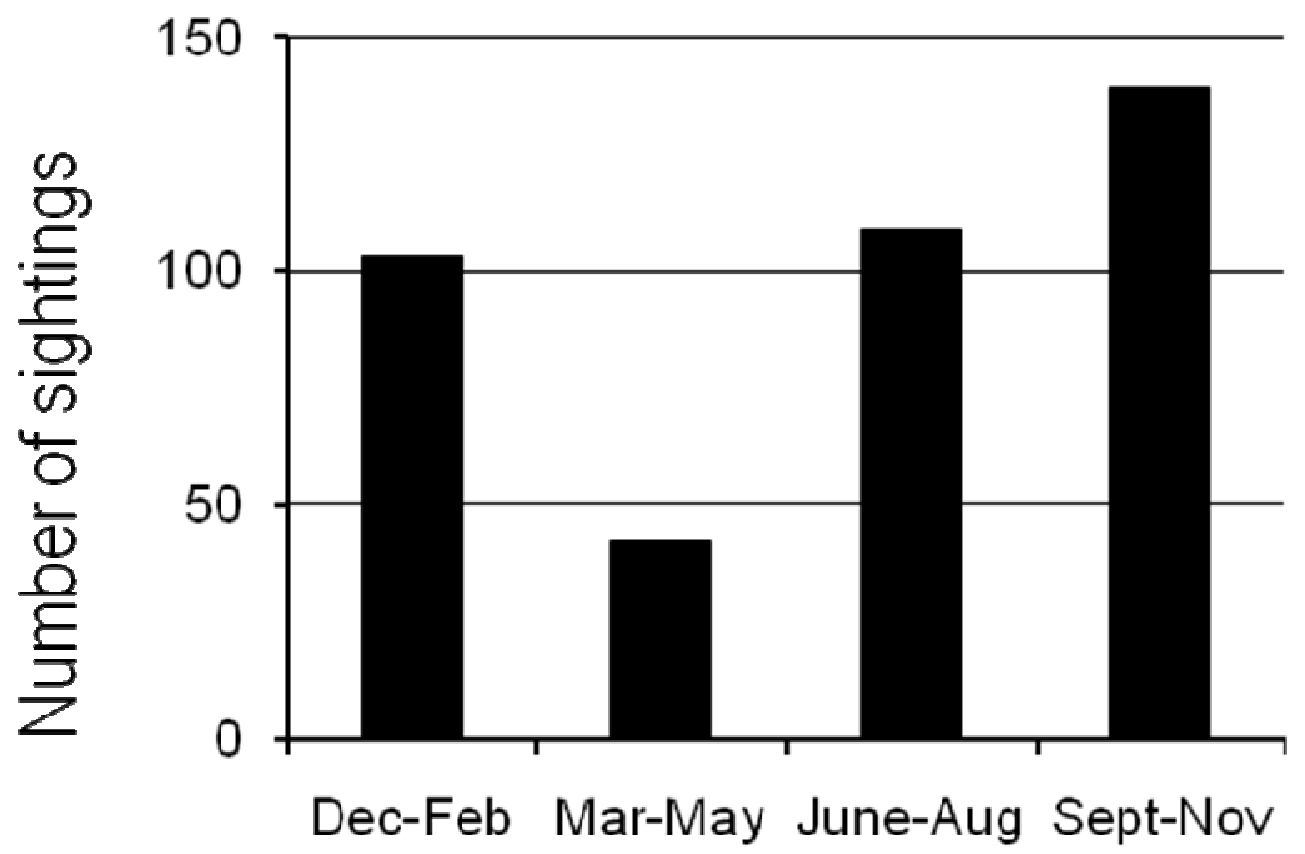

604 
$607 \quad$ Fig.4

608
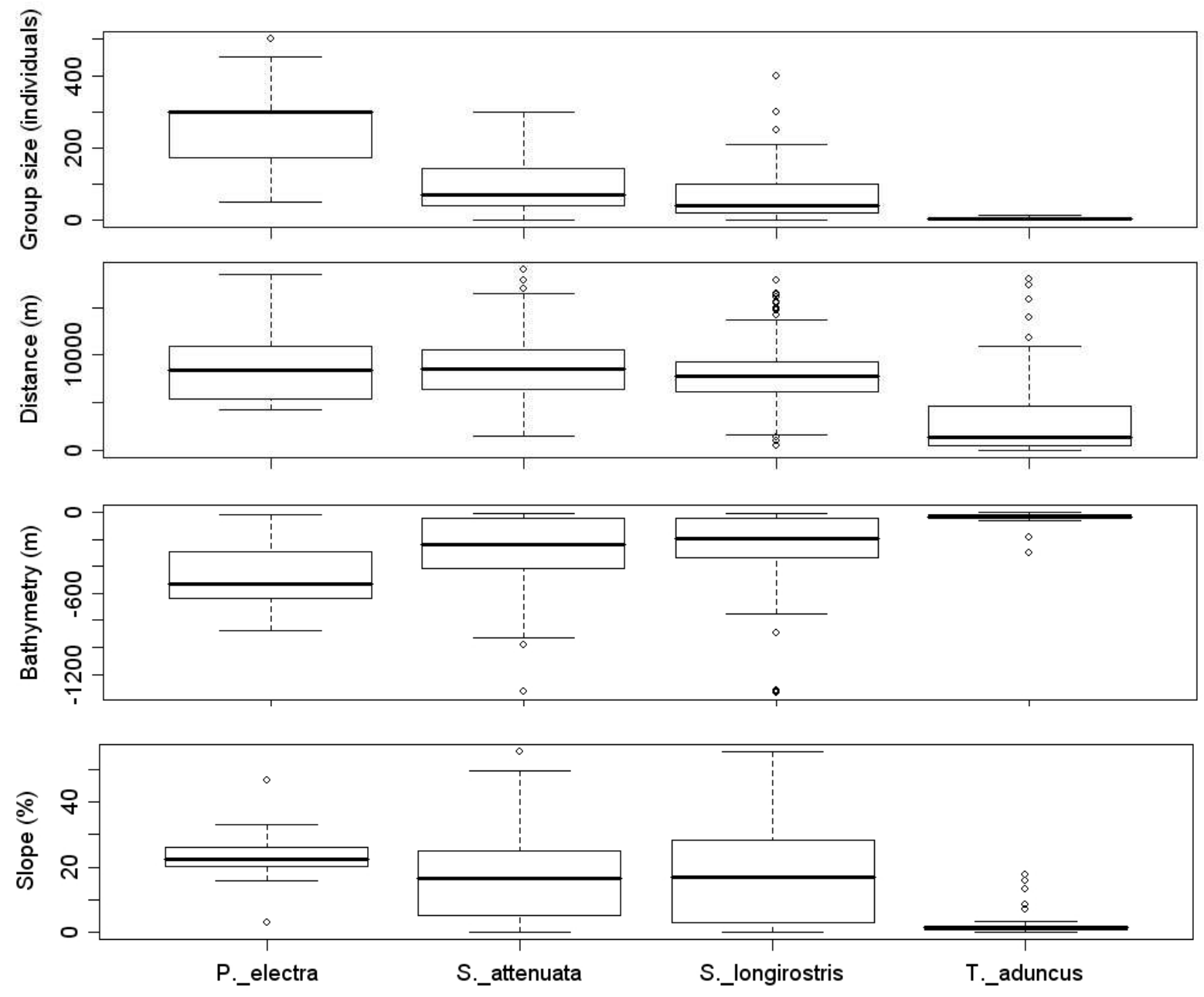
609 Fig. 5

610

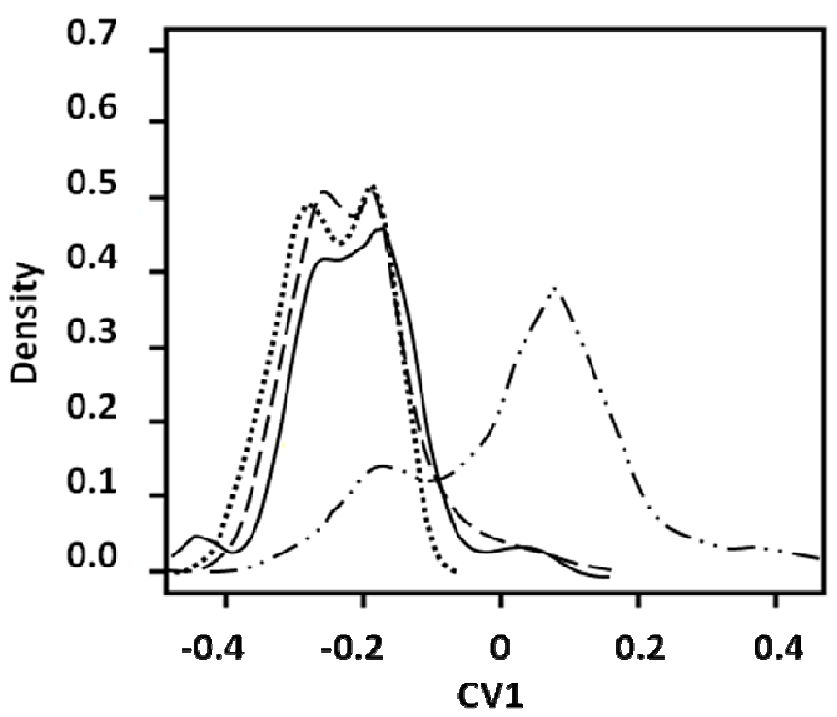

612

613 
615 Fig. 6

616

617

Skin

Blubber
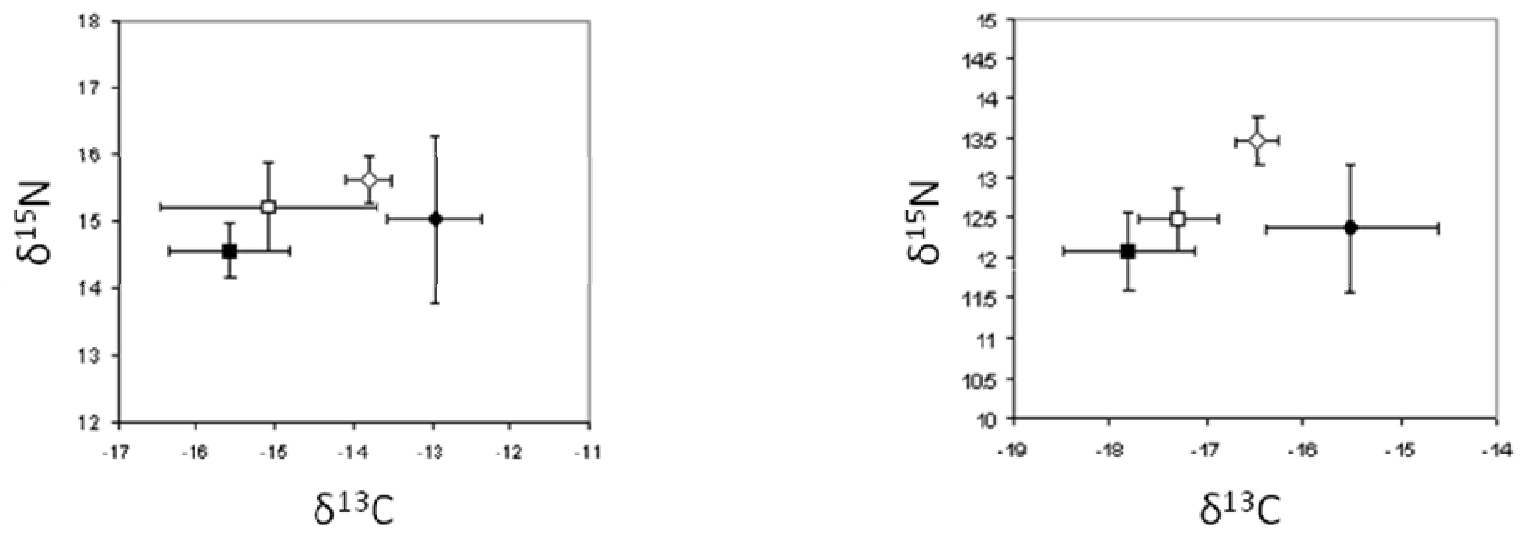

618

619

620 